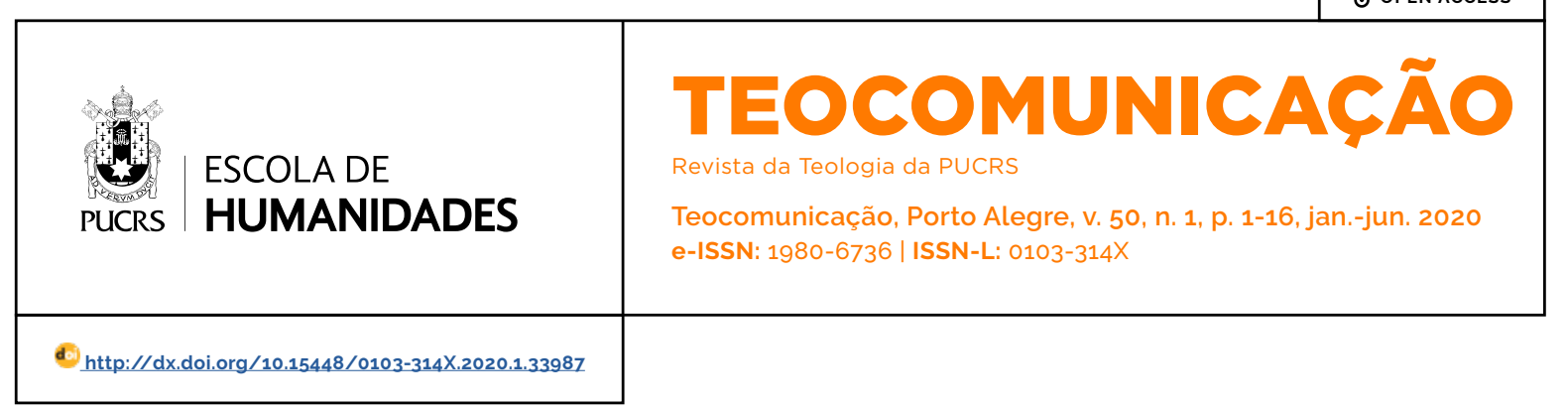

ARTIGO

\title{
Perspectivas ecumênicas numa releitura do Magnificat de Lutero
}

\author{
Ecumenical perspectives in a report of the magnificat de Lutero
}

\section{Janaina Santos Reus \\ Freitas $^{1}$}

orcid.org/0000-0001-7499-9943 janainasantosreusfreitas@gmail.com

\section{Edla Eggert ${ }^{1}$}

orcid.org/0000-0002-1980-7053 edla.eggert@pucrs.br

Recebido em: 24/4/2019.

Aprovado em: 9/1/2020

Publicado em: 05/11/2020.
Resumo: O presente texto aborda uma interpretação do Magnificat de Lutero, num movimento de argumentação baseado na experiência de leitura de duas tradições, a católica e a luterana, no entendimento que elas podem, juntas, levar a uma dialógica do modo de viver cristãmente, segundo o modelo de Maria. O objetivo é apresentar uma interpretação que tentamos fazer do Magnificat de Lutero em relação a Maria, em um diálogo ecumênico entre as duas tradições acima referendadas. Para isso, utiliza-se de revisão bibliográfica, tendo como foco central o livro O Louvor de Maria: o Magnificat, de Martinho Lutero e os possiveis diálogos desde essas duas tradições nesse início de século XXI.

Palavras-chave: Magnificat. Lutero. Humilhação. Libertação. Maria.

Abstract: The present text deals with an interpretation of Luther's Magnificat, in a movement of argumentation based on the experience of reading two traditions, the Catholic and the Lutheran, in the understanding that they can together lead to a dialogical reflection on the Christian way of living according to the model From Maria. The objective is to present an interpretation that we try to make of the Magnificat of Luther in relation to Mary, in an ecumenical dialogue between the two traditions mentioned above. For this, a bibliographical review is used, with a central focus on the book The Praise of Mary: the Magnificat by Martin Luther and the possible dialogues from these two traditions at the beginning of the twenty-first century.

Keywords: Magnificat. Luther. Humiliation. Release. Maria.

\section{Introdução}

O presente artigo apresenta a análise da interpretação de Martinho Lutero sobre o Magnificat por meio do estudo de alguns teólogos luteranos e católicos para corroborar com um estudo ecumênico sobre Maria. O texto base para essa análise encontra-se no livro O louvor de Maria: o Magnificat, da coleção Lutero para hoje, de 1999. É importante lembrar que Lutero escreveu o Magnificat a pedido do príncipe João Frederico, Duque da Saxônia, que solicitou uma resposta de como governar cristãmente. Destaca-se também que Lutero se encontrava em situação de exilio. Na apresentação do referido livro, Martin N. Dreher, escreve: 
O Cântico de Maria, conhecido também por sua palavra latina inicial, Magnificat, foi consolo para Lutero nos dias anteriores à Dieta de Worms, em 1521, quando teve que se apresentar ante o Imperador Carlos V, e foi-lhe conforto quando, com seus direitos politicos cassados, esteve exilado no Wartburgo. ${ }^{2}$

A análise de Lutero poderia ser definida como um escrito baseado no consolo da Mãe de Deus, mas também como ética política de quem vê tudo governado pela graça de Deus. Diante da leitura do Magnificat de Lutero percebe-se uma correlação direta com a abordagem de que Deus tem suas escolhas e, nesse caso, a análise está apoiada no olhar de Deus que prefere dar atenção aos pobres. Deus que faz sua opção pelos insignificantes, humilhados, exaltando os oprimidos.

Neste artigo percorremos a visão de Lutero em relação à Maria, mulher pobre, humilde, que com base na fé em Deus, profetiza a libertação, e um mundo novo, que virá em Jesus. O ponto crucial é apresentar qual a visão de Lutero sobre Maria e suas relações com a salvação, com o povo de Deus, com a atualidade e com a visão luterana e a católica atual. No intuito de colaborar para uma melhor e maior clareza quanto às manifestações de atenção e respeito à Santa Mãe de Deus, como ele mesmo menciona, por mais de 20 vezes, em sua reflexão.

Exploraremos quatro pontos: 1) Em que contexto Lutero escreve o Magnificat; 2) O Magnificat de Lutero; 3) Dinâmica da reflexão de Lutero sobre o Magnificat; 4) Desdobramentos atuais do Magnificat. Finalizamos com uma tentativa de destacar aspectos que nos sensibilizaram a indicar como percebemos as possibilidades do ecumenismo.

\section{Em que contexto Lutero escreve o Magnificat?}

O contexto em que Lutero escreve o Magnificat é um tanto quanto conturbado, tendo em vista as declarações e perseguições sofridas por ele por causa de seu trabalho relacionado as 95 teses e seu destaque à salvação por meio da graça de Deus e da fé, contestando as indulgências e abusos eclesiásticos daquele tempo. As declarações e manifestações contra Lutero culminaram, após processos disciplinares, com a bula Exsurge Domine, de 15 de junho de 1520, que o acusava de heresia. Lutero, por sua vez, queimou o referido documento. A ação de Lutero teve uma reação da Cúria, por meio da bula Decet Romanum Pontificem, de 3 de janeiro de 1521, que declarou a excomunhão de Lutero. Convocado pelo Imperador Carlos V, após negar retratação, Lutero se apresenta na Dieta de Worms. Em abril de 1521, na ocasião ele não nega suas concepções e por esse motivo foi ameaçado de proscrição, o que aconteceu em 26 de maio de 1521, no edito de Worms.

O processo de contradição da Igreja Católica para com Lutero que resultou na sua excomunhão, processo eclesiástico, e proscrição, processo civil de perda de direitos, teve início com a defesa daquilo que seus amigos chamaram de "teologia autêntica" ou teologia de Cristo (debate sobre teologia escolástica). Essa "nova teologia" questionava a escolástica e as indulgências. Entretanto, nunca teve como valor inicial o surgimento de um movimento de reforma, conforme Martin N. Dreher:

As 95 teses, cuja afixação, a 31 de outubro de
1517, é comemorada anualmente como Dia da
Reforma, de modo algum tinham a intenção
de deflagrar um movimento. Lutero nada mais
pretendia que o esclarecimento teológico de
uma questão que o envolvia como cura d'almas
e que tinha implicações para a piedade de seus
paroquianos: a indulgência. ${ }^{3}$

Após sua proscrição, a obra de Lutero foi proibida. No caminho de retorno, após a Dieta de Worms, Lutero foi "sequestrado" por companheiros do príncipe Frederico e foi conduzido a Wartburgo, lugar em que se manteve exilado. Alguns podem mencionar como um sequestro arranjado. O fato é que o príncipe determinou que ele fosse levado por um grupo de homens mascarados até o castelo de Wartburg, em Eisenach. Ali ele ficou por mais ou menos um ano, deixou sua barba crescer e adotou o pseudônimo de Jorge (Jörg) Frederico era príncipe, Sábio da Saxônia,

\footnotetext{
LUTERO, Martim. O Louvor de Maria: o Magnificat. São Leopoldo: Sinodal, 1999. p. 7

LUTERO, Martim. Obras selecionadas: os primórdios (escritos de 1571 a 1519). São Leopoldo: Sinodal; Porto Alegre: Concórdia, 2004. v. 1. p. 21.
} 
da jurisdição em que Lutero residia. Em 1521, na ocasião de sua entrevista para retratação (antes da excomunhão e proscrição), o príncipe havia negociado o salvo conduto do imperador para Lutero. O que indica é que o apoio de Frederico a Lutero não está relacionado à sua convicção quanto às suas teses, mas ao fato de lhe dar oportunidade justa de tratamento. Por fim, acredita-se que ele o protegeu. Cabe ressaltar que os laços de proximidade de Lutero com o principe podem ter se dado pelo fato de Frederico ter sido um dos fundadores da Universidade de Wittenberg, onde Martinho Lutero foi professor.

Nesse contexto de exílio, excomunhão e proscrição é que Lutero escreve o Magnificat. Pode-se perceber esse contexto como tempo de solidão, estudos e perseguição. Nessa realidade, Lutero pode ter encontrado na "humilde serva" - a doce mãe de Deus - acalento e abrigo.

\section{Magnificat de Lutero}

Lutero escreve o Magnificat a pedido do príncipe Frederico, que queria orientações de como governar de modo cristão. Lutero escreve a obra com interrupções e, por isso, justifica ao príncipe: "Faz tempo que prometi e estou devendo à Vossa Alteza uma explicação do Magnificat. Mas o desastroso comportamento de muitos adversários sempre me impediu de cumprir essa tarefa [...] demorar mais seria uma vergonha e um desaforo". ${ }^{4} \mathrm{~A}$ prova de sua obra em três folhas foi enviada ao príncipe em 31 de março de 1521 e foi concluida em setembro de1521.

Lutero traduziu Lucas 1,46b-55 para a língua alemã, que estava em uso e desenvolvimento no espaço geográfico e sociolinguístico que marcaram a formação do mesmo. ${ }^{5}$ A referida tradução com o texto original em alemão foi publicada no artigo "O Magnificat de Maria no Magnificat de Lutero", de Ivoni Richter Reimer (2016).

A análise de Lutero se deu por meio da reflexão individual de cada expressão (versículo) do
Magnificat. A título de inspiração inicial expõe-se a oração de Lutero:

\begin{abstract}
Queira essa doce mãe de Deus conquistar para mim o espirito capaz de interpretar de forma proveitosa e profunda esse cântico. Assim Vossa Alteza e todos nós podemos compreendê-lo bem e ter uma vida louvável para que, na vida eterna, possamos louvar e cantar esse Magnificat eterno. Que Deus nos ajude. Amém. ${ }^{6}$
\end{abstract}

A expressão acima pode revelar uma admiração de Lutero por Maria, ela é para ele modelo de fé e de missionariedade, na perspectiva de reação à ação transformadora de Deus. Na chave hermenêutica de interpretação do Magnificat, Maria tem interação na realização que é exclusivamente de Deus. Lutero destaca que Maria é pessoa admirável, de coração simples e puro, porque permaneceu humilde, mesmo depois de Deus ter "baixado" os olhos nela. "Maria reconhece o contemplar como primeira obra de Deus realizada nela. Esta também é a obra maior, na qual se baseiam todas as demais e da qual procedem. Quando Deus volta seu rosto para alguém ai reinam a pura graça e a bem-aventurança". E esse é o sentido do porquê todas as gerações também a contemplarão $($ Lc 1,48$)$, pois o Poderoso a contemplou primeiro. Ser contemplada por Deus é mais do que receber bens-dons d'Ele. Deus dá a uma grande multidão de pessoas.

Os bens são apenas presentes que duram algum tempo. Seu contemplar misericordioso é a herança que dura para sempre, como diz São Paulo em Romanos 6,23: "A graça é a vida eterna." Nos bens Deus dá o que lhe pertence. na contemplação misericordiosa ele se doa a si mesmo... Nos bens recebemos sua mão, na misericordiosa contemplação seu coração, Espirito, sua mente e vontade. ${ }^{8}$

Maria pode contemplar a Deus, louvá-Lo e exaltá-Lo porque antes por Ele foi amada; pode inteiramente de alma enaltecê-Lo com o Magnificat porque primeiro Ele a olhou misericordiosamente com sua vontade. Partindo dessa oração e do princípio de que a Escritura uma vez recebida por nós é partilhada por meio também das nossas

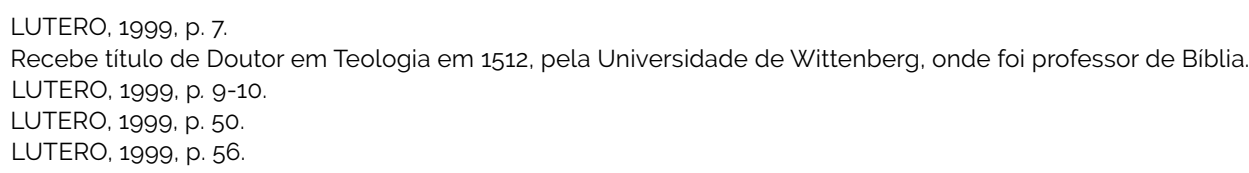


experiências, podemos compreender o quanto Lutero foi sensivel ao contexto da época para escolher o Magnificat para admoestar o príncipe. "Ora, não lembro nada nas Escrituras que sirva melhor para esse caso do que o cântico sagrado da bendita mãe de Deus". 9 Na ocasião de sua análise ele utiliza o texto para expressar o quão importante é a ação de um governante para o bem estar e a qualidade de vida de um povo. Também se percebe adjetivos e manifestações quanto à Mãe de Deus como é possivel perceber abaixo nas duas citações da introdução de sua obra:

Para entendermos este santo cântico de louvor em sua ordem, deve-se considerar que a altamente louvada virgem Maria fala de experiência própria, na qual ela foi iluminada e instruida pelo Espírito Santo. Pois ninguém é capaz de entender corretamente a Deus ou a Palavra de Deus a não ser que o tenha do Espírito Santo; todavia, ninguém o pode ter do Espírito Santo se não o experimentar, sentir ou perceber. Nessa experiência o Espírito Santo ensina como em sua própria escola; fora dela nada se ensina além de palavras que buscam a aparência e conversa vazia. É este o caso da santa virgem. ${ }^{10}$

O mesmo faz aqui a doce mãe de Cristo, ensinando-nos, pelo exemplo de sua própria experiência e por meio de palavras, como se deve conhecer, amar e louvar a Deus. Pois aqui ela se gloria e louva a Deus com um espírito saltando de alegria, dizendo que Ele havia posto o olhar nela, sendo ela humilde e nada. ${ }^{11}$

Dessas frases se verificam instruções importantes ao príncipe e manifestações valiosas quanto ao pensamento de Lutero sobre Maria. Primeiramente, o fato de atestar a presença do Espírito Santo na santa virgem, de abordar a experiência de Maria como alguém que fez sua escola, na escola do Espírito, significa direcionar para como governar cristãmente, ou seja, atuar sob a ótica do Espírito Santo, deixar-se envolver pela lógica d'Ele, no sentido de ser ensinado conforme seus desígnios, sob a iluminação do Espírito Santo, a fim de entender a vontade de Deus na história.

A explicação a respeito de governar segundo o Espírito se clarifica na expressão por Lutero mencionada:
É este o caso da santa virgem. Depois de ter experimentado em sua própria pessoa que Deus realiza nela coisas tão grandes, apesar de ter sido nada, insignificante, pobre e desprezada, o Espírito Santo lhe ensina este rico conhecimento e sabedoria: que Deus é um Senhor que não faz outra coisa do que exaltar o que é humilde, de humilhar o que é elevado, em suma, de quebraro que está feito e de refazer o que está quebrado.12

Nesse mesmo sentido, se pode refletir que para que grandes coisas aconteçam, devemos nos fazer pequenos, é a graça de Deus que tudo realiza; num entendimento que parte de baixo para cima, numa perspectiva de curvar, humiLhar. Essa visão de Lutero, em que a humildade de Maria, vista não como virtude, mas como humilhação, é vista por Deus como agradável, remete a analogia com a forma maximalista ou minimalista de ver Maria:

Muito se tem falado, num sentido, sobre as
tendências "maximalista" e "minimalista" em
Mariologia. Com a melhor intenção do mundo,
a primeira trata de afirmar de Maria o máximo
possivel, para a exaltação e louvor de Nossa
Senhora. A segunda (mais comum entre os
irmãos separados), com o desejo de proteger
a mediação única de Cristo, aceita apenas
atribuir-lhe estritamente o mínimo do que
sobre ela afirma a Escritura, inclusive com
uma interpretação redutiva. A meu modo de
ver, nem uma nem outra postura se justificam,
nem ao menos pela boa vontade. ${ }^{13}$

A visão supramencionada não está focada nos títulos dirigidos a Maria, mas ao fato de Deus ter olhado para ela, para sua humilhação. O foco está na sua nulidade e não nos seus méritos ou naquilo que ela pode representar diante do Plano da Salvação. Nesse intuito, Afonso Murad destaca que os títulos a ela concedidos devem ser purificados de exageros: "Assim, nova Eva, Mãe das dores e corredentora são imagens que extrapolam o campo de sentido do texto [...] Além disso, são interpretações ambivalentes. Têm valor simbólico e espiritual, mas devem ser purificadas de exageros e concepções unilaterais".14

Pode-se também analisar a expressão, humi- 
Lhação de Maria, no sentido de Deus ter olhado para ela como olha para o seu povo, quando Maria diz "olhou para a humilhação de sua serva" (LC 1,48). Deus viu seu estado de prostração, a aflição da nação e as orações dos humildes; e pelo fato de enviar seu redentor, deu início à obra que culminará na restauração de Sião. ${ }^{15}$ Essa humilhação não está relacionada à qualidade de Maria, mas à:

Tapeinosis (é em) seu significado mais frequente: a humilhação por causa da perseguição, da opressão pelos inimigos, de onde emana um estado de miséria. Nesse estado Deus contempla o pobre, lembra-se dele, escuta-o e o salva mediante um socorro eficaz, cujo caso típico é o Exxodo: "Gritamos então a Javé, Deus dos nossos pais, e Javé ouviu a nossa voz: viu nossa miséria (tapeinosin), nosso sofrimento e nossa opressão" (Dt 26,7); "Ele se lembrou de nós em nossa humilhação (tapeinosin)" (SL 136,23). Maria sente-se libertada por sua maternidade, como representante do povo. A vinda do Messias o salvará de sua servidão. Todos os textos do Êxodo insistem sobre a opressão, a humilhação, o serviço que os israelitas eram obrigados a prestar: estavam na escravidão (Ex 1,13-14). Foram libertos para servir a Javé. Da mesma forma Maria chama-se de "serva", título aplicado com frequência a Israel como povo. Maria acaba de receber uma mensagem que interessa a todo povo: agora fala em nome de Israel. ${ }^{16}$

Ficam expressos aí dois tipos de humilhação: aquela que provém da indignidade da escravidão e aquela ligada à pobreza, ou seja, ao pobre que é humilhado pelo rico. Murad desenvolve uma interpretação nesse sentido:

E no tempo do exilio desenvolve-se um sentido ético e espiritual para o termo. O humilde não cede diante da humilhação, mas resiste na fé. Persiste em acreditar que Deus é justo e fará valer sua causa. Assim se desenvolve a espiritualidade dos "pobres de coração", em hebraico anawin. Os pobres são forçados a se curvarem diante da força e do poder dos que os dominam. Ao se empenharem para defender sua dignidade, exercitam a fé na grandeza de Deus, nos seus projetos às vezes incompreensiveis, e reconhecem-se pequenos. Javé é o defensor dos pobres e dos humildes (ver Dt 10,17; Sl 103,6; 140,13). Maria resume este duplo sentido de "humildade". É uma mulher, pobre, de Nazaré da Galileia, com tudo o que isso significa na Palestina de seu tempo. Faz parte da multidão anônima, não pertence à família sacerdotal, não é rica nem poderosa. Mas sua atitude qualificadora é a fé perseverante, a entrega nas mãos de Deus. ${ }^{17}$

Maria nos ensina a confiar em um Deus que olha a humilhação de seu povo, que age diante dessa realidade e que é como ela diz: Senhor, Salvador, misericordioso e poderoso. Ele é digno de quem pode se depositar fé. Para a realidade de Frederico, talvez, essa manifestação de Lutero não tenha sido compreendida de forma serena, pois o contrário de ser humilde, o príncipe seria um ser poderoso:

\begin{abstract}
Os poderosos (dynastai) são a antítese dos humildes (tapeinoi), isto é, aqueles que confiam em um poder, sendo essa a única forma para seu comportamento. Em benefício próprio abusam dos que são mais fracos, oprimindo-os (cf. Jó 22,6-9) e, com frequência, estão representados no principe (Mq 3,1-4; Jr 22,13-27; Ez 21,30; 34,1-6). ${ }^{18}$
\end{abstract}

Muitas vezes príncipes e governantes são orgulhosos a ponto de oprimir os mais fracos porque confiam única e exclusivamente em seus bens, sejam eles materiais, intelectuais ou espirituais. Para esses Lutero diz:

Temos de nos afastar não dos bens de Deus, mas do mau apego a eles. Assim podemos renunciar a eles ou usá-los com tranquilidade. para que nos apeguemos somente a Deus. Isso deveriam saber todos os príncipes e autoridades que não se satisfazem com o confessar da justiça, mas também querem conquistá-la e vencer sem medo de Deus. Cobrem o mundo de sangue e miséria, acham que agem bem e com justiça. ${ }^{19}$

Não menos importante é a forma como Lutero declara quem é Maria: "Doce mãe de Deus". Ao chamá-la de doce parece estar ele mesmo adjetivando o que pensa sobre ela, talvez uma doçura que o próprio Lutero estivesse necessitando no momento de exílio que estava vivenciando. Doce mãe, mãe de Cristo, não é somente uma expressão, mas uma declaração de quem crê que ela é mãe do Messias, do Salvador. Mãe que com suas palavras ensina, dá o exemplo de como alegrar o Senhor, de que forma agradá-Lo.

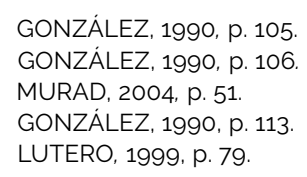


As palavras de Maria no Magnificat são de quem experimentou a ação do Espirito Santo. Ela é capaz de falar a respeito de Deus com estima, mesmo sendo ela um nada. Não se referenda sobre uma doçura originária, mas daquela que aperfeiçoa, a doçura do amor, alegria e fortaleza que Maria por estar em Deus pode dar. É como se essa doçura pudesse emitir um odor suave e ao mesmo tempo firme (süße, em alemão: adorável, afável, ameno, amável, atraente, açucarado, bondoso, bonito, bonitinho, brando, cativante, cego, comovedor, delicioso, doce, docemente, docinho, embotado, encantador, enternecedor, esbelto, fascinante, fofo, gentil, gracioso, lindo, meigo, obtuso, suave, tocante).

É interessante mencionar que durante o Magnificat, Lutero utiliza por mais de 20 vezes a expressão "doce mãe de Deus". Maria não agiu com prepotência ou orgulho, do contrário, "ela não se atribuiu absolutamente nada (...) Não foi mais do que um alegre albergue e uma serviçal anfitriã desse hóspede. Por isso ficou com tudo para sempre". 20 Ou seja, Maria se colocou como um nada e por graça pode ser apreciada como mãe de Deus. Enfim,

nisso estão toda a sua honra e bem-aventurança. Por essa razão ela é uma pessoa especial dentre o gênero humano. Ninguém se iguala a ela, porque ela tem um filho com o Pai celeste. E que filho! E ela mesmo atribui tudo isso a graça de Deus e não a seu mérito. É preferivel anular méritos de Maria a dinimuir a graça de Deus. ${ }^{21}$

Mesmo sendo mãe de Deus, Lutero destaca que "Maria não quer ser um ídolo. Ela nada faz. Deus é que faz todas as coisas. Devemos suplicar a ela para que, por amor a ela, Deus faça o que pedimos.".2 Os católicos concordam com esse pensamento, mesmo venerando Maria de modo especial, compreendem que é Deus quem tudo faz. A mediação de Maria para os católicos é entendida como

um serviço permanente à comunidade cristã. Ela não substitui a de Cristo, não eleva orgulhosa- mente o ser humano, nem subestima a soberania da Palavra de Deus. A maternidade espiritual de Maria é puro serviço, oferta, trilha que aponta e conduz para o único caminho: Jesus. ${ }^{23}$

Lutero compara Maria com uma oficina onde Deus realiza sua obra. É Ele quem tudo opera e conserta. Maria é matéria pura manipulável nas mãos d'Ele que nela tudo pode fazer, pois a mesma é inteiramente aberta à ação de Deus. Deus agindo nela fez coisas estupendas, mas ela, cheia das graças e das maravilhas de Deus, continuou sendo a mesma. É no mínimo intrigante ver que ao receber a mensagem de que seria a mãe de Deus sai, não para anunciar a todos o quão importante tinha se tornado, ao contrário, sai para servir:

\begin{abstract}
Eu sou apenas a oficina na qual ele trabalha... Maria atribui todas as coisas inteiramente a Deus. Não reclama para si nenhuma obra, nehuma honra, nenhuma glória. Comportase como antes quando ainda não tinha nada dessas coisas.Também não quer mais honra do que antes. Não se vangloria, não se gaba de que se tornou mãe de Deus. ${ }^{24}$
\end{abstract}

O fato é que Maria é mãe de Deus, pois desde o início, ao contemplar o mistério da encarnação, a Igreja foi compreendendo o mistério da mãe do Verbo feito homem. No Concilio de Éfeso (431) foi solenemente declarado como dogma a maternidade divina. Maria é mãe de Deus (Theotókos), pois por obra do Espírito Santo concebeu e deu à luz a Jesus Cristo, o Filho de Deus, consubstancial ao Pai. Ele, ao vir ao mundo, tornou-se homem como nós. Assim, o Concilio se tornou uma espécie de marca de autenticidade no dogma da encarnação. Jesus sendo uma única pessoa com duas naturezas (humana e divina) não pode ser dividido em duas pessoas. Por ser mãe de Jesus, Maria é, portanto, mãe de Deus.

Em 451, o Concílio de Calcedônia declara, baseado na contribuição de Nestório, que Maria é "mãe segundo a humanidade", ou seja, mãe do Filho de Deus encarnado; essa declaração esclarece que Maria não é mãe da Trindade. A Lumen 
Gentium ratifica o dogma e declara verdadeira a maternidade biológica, humana e natural, de Maria, ao mesmo tempo em que uma maternidade plenamente espiritual, como verdade cristológica e mariológica. O capítulo 8 da Lumen Gentium insere a devoção mariana no mistério de Cristo e na comunidade eclesial. Em 1975, o papa Paulo VI, escreveu o documento O Culto à Virgem Maria (Marialis cultus) apresentando-a como referência para a vida dos cristãos e convidando a evitar exageros que dificultem o diálogo ecumênico.

Para os católicos, Maria ocupa um lugar único, mais alto depois de Cristo e mais perto de nós ( $L$ G 54), mas a graça que ela comunica, não surge dela e ela não a retém. Jesus é o Senhor e Maria aquela que nos ajuda nessa travessia. Entretanto, essa maternidade mediadora, atualmente, não é vivida por luteranos, primeiramente porque nessa visão Jesus é o único mediador e também porque, a partir de Lutero, ressoa a tese de que o ser humano é justificado somente pela fé e não pelas obras da Lei. E como o ser humano está sempre na iminência do pecado, não há como seres humanos se colocarem na mediação entre a humanidade e Deus.

Na verdade, já pensavam assim - Maria, mãe de Deus - os Santos Padres. Por exemplo, Santo Atanásio, em 373, na homilia de Natal, declara:

Nosso Senhor Jesus Cristo, queridos irmãos, que criou todas as coisas desde a eternidade, se converteu hoje em nosso salvador, ao nascer de uma mãe. Quis nascer hoje no tempo, para conduzir-nos até a eternidade do Pai. Deus se fez ser humano para que o ser humano de fizesse Deus; hoje se faz ser humano o Senhor dos anjos para que o ser humano possa comer o pão dos anjos. ${ }^{25}$

Os luteramos, também têm uma fórmula para atestar que Maria é Mãe de Deus: "A 'fórmula da concórdia' da Igreja Luterana, após a morte de Lutero, em 1557, diz: Nós cremos, ensinamos e confessamos que Maria é justamente chamada Mãe de Deus e que o é verdadeiramente". 26

Quando Lutero menciona que ela se gloria e louva a Deus saltando de alegria, não quer dizer vangloria, pois conforme 2 Cor 10,17, "quem se gloria, que se glorie no Senhor." Ela engrandece exclusivamente a Deus, atribui tudo a Ele. Maria se coloca como nada, humilde serva. Nesse sentido, indica para quem Deus olha, com quem Ele prefere estar, como no SI 147,6: "lahweh sustenta os pobres e rebaixa os ímpios"; ou ainda 1 Cor 1,26-31:

Vede, pois, que sois irmãos, vós que recebestes o chamado de Deus; não há entre vós muitos sábios, segundo a carne, nem muitos poderosos, nem muitos de família prestigiosa. Mas o que é loucura no mundo, Deus o escolheu para confundir os sábios; e o que é fraqueza no mundo, Deus o escolheu para confundir o que é forte; e, o que no mundo é vil e desprezado. o que não é. Deus escolheu, para reduzir a nada o que é. A fim de que nenhuma criatura possa se vangloriar-se diante de Deus. Ora, é por ele que vós sois em Jesus Cristo, que se tornou para nós sabedoria proveniente de Deus, justiça, santificação e redenção. A fim de que, como diz a Escritura, aquele que se gloria, glorie-se no Senhor.

Deus está ao lado dos humildes, daqueles que se humilham para estar com Ele, dessa forma Ele pode agir plenamente. Esse é o caso da virgem Maria. Deus olhou para ela pobre, a preferiu à filha de príncipes, reis e sacerdotes. Esse pensamento colabora com a perspectiva da Teologia da Libertação latino-americana:

Caso se leve a sério o que dissemos - e não só à base de uma leitura fundamentalista dos textos - a ressurreição de Jesus é esperança em primeiro lugar para os crucificados da história. Deus ressuscitou um crucificado e a partir de então há esperança para os crucificados. Estes podem ver em Jesus ressuscitado o primogênito dentre os mortos, porque em verdade - e não só intencionalidade - o reconhecem como irmão maior. Por isso poderão ter a coragem da esperança em sua própria ressurreição, e poderão ter ânimo de viver já na história, coisa que supõe um "milagre" análogo ao que aconteceu na ressurreição de Jesus. Existe, portanto, uma correlação entre ressurreição e crucificados, análoga à correlação entre Reino de Deus e pobres. ${ }^{27}$

Deus tem como característica olhar para o que consideramos insignificante. Existe uma forte relação entre o pobre, o desprezado, o sofredor

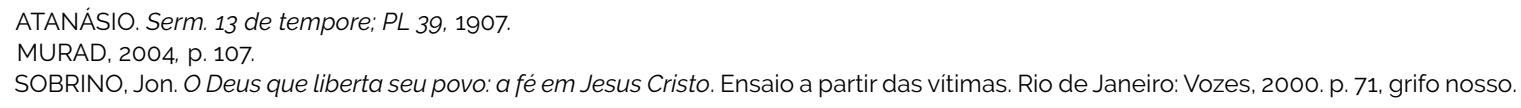


e Deus. A partir das situações de indignidade humana resultantes das relações de poder é possivel se alegrar com as manifestações de graça e misericórdia de Deus. Ser insignificante nos aproxima de Deus. E parece ser dessa forma, a indicação de Lutero para a governança do Príncipe Frederico: Quem quiser governar cristãmente, dê preferência aos pobres. "Essa é a fé em um Deus que se fez um de nós e que se manifesta no testemunho do amor prioritário de Jesus Cristo pelos pobres". ${ }^{28} \mathrm{~A}$ razão é clara e exigente, porque "tudo o que tenha relação com Cristo tem relação com os pobres, e tudo o que está relacionado com os pobres clama por Jesus Cristo: 'Tudo quanto vocês fizeram a um destes meus irmãos menores, o fizeram a mim."29 Governar cristãmente significa governar com Cristo, da forma que Ele e o Pai fazem, em atenção aos pobres.

Afonso Murad, no seu livro Maria, toda de Deus e tão humana, afirma:

No sermão da planície, Jesus deixa claro que o Reino de Deus se destina em primeiro lugar aos pobres. [...] De onde vem essa preferência? Não é que os pobres sejam bonzinhos ou tenham mais qualidades que os outros. Deus escolhe em primeiro lugar os pobres porque Ele é misericordioso e se volta sobretudo para quem necessita mais. Trata-se de uma estratégia de seu amor universal. Ama igualmente a todos, mas socorre quem mais precisa. ${ }^{30}$

Para Lutero, a estranheza com que Maria Lidou com a saudação e a visita do anjo, confirmam seu próprio sentimento de nulidade, de humilhação, pois talvez, se a visita fosse à filha de um principe, a mesma a teria percebido como normal, ou seja, teria pensado ser merecedora. Deus quis olhar para ela, Ele quem a agraciou. Nessa perspectiva de escolha de Deus diante dos humildes e oprimidos afirma Lutero:

Após a opressão, fica evidente que a força estava oculta na fraqueza. Cristo estava impotente na cruz. Justamente ali ele mostrou o maior poder; venceu o pecado, a morte, o mundo, o inferno, o diabo e todo o mal. Neste sentido, os mártires foram fortes e venceram. Também são vencedores ainda hoje os sofredores e oprimidos. ${ }^{31}$

Nos humildes, Deus manifesta o seu braço poderoso, o seu poder, fazendo-os vencedores. "Os ricos permanecem famintos e sedentos, mas os que buscam o Senhor não têm carência de qualquer bem" (SI 34,10). Deus é o maior bem, é Ele que providencia todas as coisas. Cabe ressaltar que essa humildade também pode ser encontrada nos ricos, nos príncipes, desde que as coisas sejam vistas com os olhos da humildade. Por exemplo, "a rainha Ester trazia uma rica coroa sobre a cabeça. Mas a seus olhos era um pano imundo".32

Na verdade, não é que devamos viver sem honra, porque para viver honrosamente é necessário ter honra, entretanto, o que Lutero ressalta é que toda honra deve ser devolvida a Deus, ela deve ser santificada e como bem precioso de Deus que nos foi dado deve ser em forma de agradecimento retornada. Agindo assim, estamos demonstrando que reconhecemos a obra de Deus em nós. É que a priori, Deus não julga conforme as aparências e as formas externas se são ricas ou pobres, se estão em posições altas ou baixas, mas segundo o espírito, isto é, como se comportam nessas condições. Enfim, não é o que se tem que determina a nulidade de diante de Deus, mas o modo como se portar, agir e se apegar ou não aos bens materiais. A humilhação, a santidade de vida, está atrelada à total submissão a Deus, na consideração de que tudo é Dele e para Ele.

Ao contrário do que se imagina a humildade não é uma qualidade típica dos fracos, mas de todo o ser humano a caminho da maturidade. $\mathrm{E}$ quanto mais uma pessoa exerce cargos complexos de autoridade, na Igreja e na sociedade, mais necessita desenvolver a humildade, para que o poder não se desvirtue em dominação e autoritarismo. Pois a grande tentação do poder é a prepotência e o orgulho: a pessoa engrandece a si mesma e não a Deus, ao contrário do que Maria proclama no Magnificat. ${ }^{33}$

28 CONSELHO EPISCOPAL LATINO-AMERICANO. Documento de Aparecida: texto conclusivo da $\vee$ Conferência Geral do Episcopado Latino-Americano e do Caribe. 3. ed. Trad. Luiz Alexandre Solano Rossi. Brasília: Edições CNBB; São Paulo: Paulus; Paulinas, 2007. p. 128.

29 CONSELHO EPISCOPAL LATINO-AMERICANO, 2007, p. 129.

30 MURAD, 2004, p. 45

31 LUTERO, 1999, p. 84

32 LUTERO, 1999, p. 42.

33 MURAD, 2004, p. 50. 
A exemplo de Maria, Lutero alerta que o governante deve além de ser humilde, ser temente a Deus e considerar-se única e exclusivamente depende da sua graça. Pois, o comando de todas as coisas está originariamente na sua graça. Não são as obras que o governante faz que irão salvá-lo ou identificá-lo como cristão. Para Lutero, "na realidade, é a fé que, sozinha, torna todas as outras obras boas, agradáveis e dignas pelo fato de confiar em Deus e não duvidar que, perante Ele, tudo o que a pessoas fizerem está bem feito".34 $\mathrm{A}$ obra é boa se encontra seu coração na fé em Deus.

A verdade é que governantes e poderosos, nessa terra, sempre teremos, entretanto, é importante que eles tenham consciência de que Deus "não tolera que abusem e pratiquem injustiça contra os piedosos", 35 ao contrário, Ele exalta os humildes de coração.

Assim, Lutero ressalta para o príncipe: "Quando um Senhor ou uma autoridade não tem amor a seu povo e apenas se preocupa com seu próprio bem-estar, e não em como melhorar as condições de vida de seu povo, este já está perdido. Exerce a sua autoridade somente para a perdição da alma." ${ }^{36}$ E dá o conselho: "Assim ficam duas coisas: o amor de Deus e sua misericórdia, como canta o quinto versículo. Com isso me confia a Vossa Alteza, que seja encomendada a Deus para um bom governo. Amém."37

A análise segue nos ensinando sobre o quanto Deus tem preferência pela misericórdia, é sua obra mais nobre e garantida. Ela perpassa de geração em geração (Lc 1,50). Nesse sentido, diz Santo Agostinho: "É mais fácil que Deus contenha a ira do que a misericórdia. É mesmo assim! A ira de Deus dura um instante, ao passo que a sua misericórdia é eterna". ${ }^{38}$

Ressaltamos a importância da alegria com que Maria Louva a Deus. Louvar a Deus com alegria, reconhecê-Lo como soberano. Conforme Isaías
12,6: "Ergue alegres gritos, exulta, ó moradora de Sião, porque grande no meio de ti é o Santo de Israel." E ainda é possivel verificar de onde vem a fortaleza de Maria:

Neemias disse-lhes: Ide para as vossas casas, fazei um bom jantar, tomai bebidas doces, e reparti com aqueles que nada têm; porque este dia é um dia de festa consagrado ao nosso Senhor; não haja tristeza, porque a alegria do Senhor será a vossa força $(\mathrm{Ne} 8,10)$.

A alegria que mencionamos não se refere à satisfação pessoal; ao contrário, é uma alegria que foge a qualquer estereótipo humano, é a alegria centralizada em Deus. Maria em seu canto exalta a obra de Deus nela e no povo (Israel). É um hino que nasce de um coração agradecido e voltado para aquele que a criou. O tema central do Magnificat é Deus, Ele é o protagonista, Maria tem sua experiência como base num olhar retrospectivo da obra de Deus na história. Seu canto proclama a ação salvíica de Deus, de misericórdia, poder e graça. Maria nos ensina que a verdadeira alegria não está na satisfação própria, mas em louvar e bendizer a Deus, numa ação não individualista, mas que ecoa a voz com a voz de todos.

Lutero sugere que a alma de Maria está com alegria excessiva, pois brota de dentro do Espírito e é essa alegria que move a doce Mãe de Deus a enaltecê-Lo inteiramente.

Como se quisesse dizer: "Minha vida, com todos os meus dons, se movimenta no amor de Deus, em louvor e grande alegria. Deixo de ser dona de mim mesma. Antes sou agradecida do que exalto a mim mesma, para o louvor de Deus." ${ }^{39}$ Essa explosão de alegria, descrita pelo evangelista Lucas, manifesta um novo tempo, o tempo em que Jesus está conosco. 40

Também, por esse motivo,

A santa Mãe não diz: "minha voz" ou "minha boca", também não: "minha razão" ou "minha vontade" engrandece o Senhor. Muito antes a santa mãe diz: "Minha alma o engrandece."

\footnotetext{
LUTERO, Martim. Obras selecionadas: o programa da Reforma (escritos de 1520). São Leopoldo: Sinodal; Porto Alegre: Concórdia, 2004, v. 2. p. 104

LUTERO, 1999, p. 90.

LUTERO, 1999, p. 113

LUTERO, 1999, p. 113.

Enarratio Psalmos, 76,11 apud Misericordiae Vultus, 2015, p. 31.

LUTERO, 1999, p. 18.

40 Cf. MURAD, 2004
} 
Isso quer dizer, toda a minha vida, todo o meu ser, meus sentidos e minhas forças atribuem grandes coisas ao Senhor. ${ }^{41}$

A verdade é que a santa Mãe enaltece o Senhor imensa e inteiramente, de forma a colocar sua vida a bendizê-Lo. Maria exulta e nos ensina a exultar a Deus, podemos aprender com ela a ordem certa de elogiá-Lo: primeiro Senhor, depois Salvador, depois mencionar suas grandes obras, pois essa é uma forma nobre de louvar a Deus. Assim, o amamos e louvamos por aquilo que Ele é, sem interesses de receber nada em troca, enfim, com ela aprendemos o jeito puro de engrandecer a Deus.

Para Lutero, o Cântico de Maria era tão essencial que seria importantíssimo sabermos cantá-lo verdadeiramente e para isso deveriamos agir como Maria: "Ela permite que Deus atue nela de acordo com sua vontade e não tira para si mais do que um bom consolo, alegria e confiança em Deus". ${ }^{2}$ Assim, o canto estaria provido de graça e poderíamos eternizá-lo.

O Magnificat eterno significa o desejo de com ele aprender, de que esse cântico pode revelar o caminho de proximidade de Deus e de como agradá-Lo. É um canto de gratidão a Deus, alegria, louvor, consciência, cidadania e que lembra que a humanidade faz parte da História da Salvação. Esse canto se atualiza e se eterniza na medida em que sua essência de engrandecimento a Deus é vivida. Voltando ao sentido do porquê Lutero escreveu essa obra, será possivel dizer que essa é mais uma dica essencial ao príncipe: como Maria engrandecer a Deus e não querer ser engrandecido.

Maria não deve ser engrandecida, afirma Lutero. Diz ele que é preciso "vê-la diante de Deus e muito abaixo de Deus." 43 E ainda completa: "Na sua opinião, haveria algo mais bonito para ela do que se você, por meio dela, encontrasse Deus e aprendesse a confiar nele? Maria não quer que você venha a ela, mas que você encontre Deus através dela".44 Entretanto, Lutero a considera bem-aventurada, e menciona uma forma de declará-la assim:

O termo grego makariousin significa mais do que "dizer bem-aventurada" ou "tornar bem-aventurada". Mas isso não deve limitar a palavras, ajoelhações, inclinação da cabeça, tirar o chapéu, fazer imagens, construir igrejas - os maus também fazem isso. Para tanto se deve usar todas as forças e se precisa de uma sinceridade total. Isso acontece quando, por sua nulidade e pelo misericordioso olhar de Deus. o coração é tomado de alegria e prazer em Deus por meio dela e quando se diz e pensa de todo o coração: Ó bem-aventurada Maria! Este "bem-aventurada" é a maneira de honrá-la. ${ }^{45}$

É preciso concordar com Lutero que não são as obras que nos proporcionarão à salvação. Entretanto, isso não quer dizer que alguém que exercite a piedade popular não a conquiste. Numa analogia, é possivel afirmar que as devoções não podem se tornar mágicas; em contrapartida não significa dizer que quem as pratica é supersticioso ou não tem Deus como Senhor. A piedade popular pode ser sincera.

É importante lembrar que o Cântico de Maria é pronunciado após a visita de Isabel, ou seja, ele é uma resposta concreta da humilde serva ao anúncio do anjo e à saudação de Isabel. Ela, diante da anunciação e da saudação de Isabel, permaneceu humilde e, na avaliação de Lutero, humilhada. Deus olha para o que é pequeno e ela sabe disso, porque afirma em seu canto. Mas isso tudo é graça de Deus e não de Maria, é preciso honrar a Deus e contemplar a insignificância de Maria. Deus está atento aos desprezados e não os despreza, ao contrário, deles se aproxima. "Quanto mais baixo alguém está, tanto melhor Ele o enxerga".46

Essa forma de Deus ver as pessoas é uma grande orientação para o príncipe. Ele precisa aprender a olhar para baixo, para os insignificantes, os pobres, os desprezados, os humilhados, os doentes e vendo-os, utilizar do seu governo para ajudá-los. "Eles olham para cima e não para baixo. Se olhassem para baixo, veriam muitos que não têm sequer a 
metade do que eles têm. Mas, mesmo assim, estão satisfeitos com Deus e o louvam".47

Essa resposta de Maria, após a visita de Isabel, é um louvor com conotação de intimidade com Deus, mas também é social como já referendado. O cântico de Maria é um eco forte que se liga, une. Ele se interliga perfeitamente com as bem-aventuranças:

Erguendo então os olhos para os seus discípulos, dizia: Felizes vós, os pobres, porque vosso é o Reino de Deus. Felizes vós, que agora tendes fome, porque sereis saciados. Felizes vós, que agora chorais, porque haveis de rir. Felizes sereis quando os homens vos odiarem, quando vos rejeitarem, insultarem e proscreverem vosso nome como infame, por causa do Filho do Homem. Alegrai-vos naquele dia e exultai; porque no céu será grande a vossa recompensa; pois do mesmo modo seus pais tratavam os profetas (Lc 6, 20-23).

É expressão de uma mesma realidade, da escoLha de Deus por aqueles que "são menos". Parece perturbador uma mulher tão espiritual e doce, como diz Lutero, falar de coisas tão fortes. Mas é o estilo biblico de libertação aqui em evidência, não é um pedido de troca de lugares, ricos fiquem pobres e pobres fiquem ricos, é algo a mais, no sentido teológico significa a superação das situações de dominação. Essa expressão incentiva a uma vida cristã inserida no mundo politico, social e ambiental. Talvez essa seja uma conotação difícil de entendimento a um governante. O fim da dominação poderia significar um novo empoderamento.

Esse empoderamento pode significar o seu serviço como atuação no mundo, como expressão do amor de Deus, lembrando que "ninguém serve a Deus senão aquele que deixa Ele ser Deus e permite que suas obras atuem nele".48 Lutero considera a essência e a vivência do Magnificat como grande obra de Deus. "Cantamos o Magnificat diariamente em voz alta e com grande pompa, mas silenciamos cada vez mais seu verdadeiro tom e sentido. Mas o texto continua firme. Se não ensinarmos essas obras de Deus e não as aceitarmos, também não haverá serviço de Deus".49
Servir a Deus não significa orgulho, vaidade ou honraria, mas sim, comprometimento com a misericórdia que Deus deseja ser revelada. É preciso como Maria ser uma oficina em suas mãos. "Quem se faz poderoso, sábio e entendido, não compreende a originalidade do Reino de Deus. Porém, aquele que está no grupo dos 'pequeninos' pode entrar no mistério do Pai e de sua vontade, como discípulo".50 Ser discípulo de Jesus é ser humilde no sentido da palavra de origem latina:

\begin{abstract}
A palavra humildade evoca húmus da terra. A pessoa humilde tem os pés no chão, conhece sua força e sua fraqueza. Compreende-se como terra a serviço da vida, como o húmus para a planta. Bem diferente do orgulhoso e arrogante, que concentra sua existência em si próprio e cultiva o narcisismo. ${ }^{51}$
\end{abstract}

A título de conclusão desta cessão, cita-se Lutero: "Por meio do Espírito Santo, sem a concorrência de um ser humano, fez nascer para Abraão a descendência, um filho natural de uma de suas filhas, da imaculada virgem Maria".52

\section{Dinâmica da reflexão de Lutero sobre - Magnificat}

Basicamente, Lutero utilizou-se de alguns pontos essenciais ao refletir o Magnificat:

a) Político: sua análise foi uma resposta ao príncipe João Frederico que salienta que o governo deve olhar para os pobres como Deus olha, utilizando seu cargo para resgatar a dignidade. O Duque da Saxônia queria saber como uma autoridade poderia governar cristãmente. A dinâmica de cunho social e econômico foi permeando a análise de Lutero, no intuito de conduzir o príncipe, de quem Lutero declara-se subalterno, a utilizar-se de seu cargo politico para fazer o bem, ou seja, o bem comum. Lutero toma as expressões de Maria para ratificar seu canto profético que adverte a elevação das pessoas e seus direitos básicos, fazendo do poder e da lei instrumentos para servir o povo. Colabora

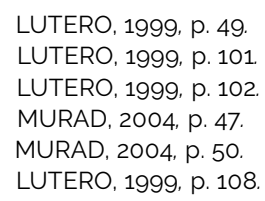


com essa afirmação a seguinte citação: "Todos nós esperamos que, no futuro, Deus coloque em suas mãos o governo da Saxônia. Isso será um grande e precioso feito se der certo".53

b) Bíblico: como bom professor de Bíblia e teólogo, Lutero faz uso daquilo que mais conhece e acredita: a Sagrada Escritura. É com ela que ele faz suas reflexões e dá conselhos ao príncipe. A escolha do trecho biblico Lc 1,45-56 atesta sua confiança na Palavra de Deus. Ali encontra alento e sustento. $E$ a partir desse trecho biblico que indica coisas muito significativas, como por exemplo: Como se pode louvar a Deus e como agradá-Lo. A ação de Deus é sempre misericordiosa; Os pobres serão exaltados; Maria é exemplo de fé a ser seguido; Maria é doce mãe de Deus; Humilhação não é vergonha, mas graça diante de Deus; Maria é bem-aventurada. Isso indica aos políticos a consciência de que o bem-estar de muita gente depende deles. Os governantes devem se deixar guiar pela graça de Deus; Deus olha para baixo, para os humildes.

[Lutero] articulava o principio sola scriptura com o principio sacra scriptura sui ipsius interpres (a Sagrada Escritura é seu próprio intérprete), que também implicava que a autointerpretação da Escritura e a interpretação com o Espírito Santo coincidem. De acordo com Lutero, deve-se buscar na Biblia tudo o que promove a Cristo e também tudo o que Cristo promove, sendo ele a referência central e o referencial que legitima e/ou autoriza a análise. ${ }^{54}$

Diante do exposto entende-se a escolha de um texto da Sagrada Escritura para responder ao príncipe.

c) Colocar-se na brecha: "E busquei dentre eles um homem que estivesse tapando o muro, e estivesse na brecha perante mim por esta terra, para que eu não a destruisse; porém a ninguém achei" (Ez 22,30). Fazendo uma analogia, trata-se de haver espaço vazio num lugar, por exemplo, num muro, uma brecha, um buraco. Colocar-se na brecha seria inserir-se nesses espaços para que o muro ficasse fechado, ou seja, para que ninguém, nenhum inimigo entrasse na ci- dade por ele. Referimo-nos a colocar-se no lugar de alguém e por ele pedir, interceder. Parece contraditório, Lutero que ensinava a salvação como única mediação, a de Jesus Cristo, foi ele mesmo intercessor. É como se ele quisesse se colocar dentro das feridas dos humildes e por eles clamar. Ele estava disposto a mostrar ao príncipe que Deus se agrada de pessoas assim. É um colocar-se diante de Deus buscando sua orientação. Pela reflexão do Magnificat percebe-se que Lutero soube olhar para baixo. Por vezes, sua reflexão nos remete a uma súplica pelos desvalidos. Deus fez nele sua obra de preferência pelos insignificantes.

d) Tempo verbal nas expressões: "Faz todas as coisas"; "Vai de geração em geração"; "Age poderosamente"; "Destitui os grandes senhores"; "Sacia os famintos"; "Acolhe Israel". Todas as conjugações verbais são traduzidas no tempo presente, ou seja, Deus continua realizando, ou melhor, realiza sua obra, seu poder, hoje, aqui e agora. Esse pensamento leva a ter fé na ação de Deus no tempo presente, pois Ele não só fez, Ele faz.

e) Reapresentar as ideias teológicas fundamentais: "A paz tem somente uma origem: quando se ensina que nenhuma obra, nenhuma prática externa nos torna retos, justos e bem-aventurados, mas somente a fé, isto é, a boa confiança na graça visivel de Deus que nos é prometida"55; Por causa desse engano e falsa disposição da alma igualmente todas as obras do corpo são más e reprováveis". ${ }^{56}$

\footnotetext{
Justamente em nossos dias prevalece um detestável abuso no mundo com a distribuição e venda de boas obras. Alguns espiritos atrevidos querem ajudar outras pessoas, especialmente aquelas que vivem ou morrem sem obras próprias de Deus, como se elas mesmas tivessem sobra de boas obras. ${ }^{57}$

Seu coração (diz Deus) está tão endurecido quanto a bigorna de um ferreiro (Jó 41ss). É o corpo do diabo. Por isso também atribui tudo ao diabo nessa mesma passagem. Em nossa época, mais do que ninguém o papa e seus seguidores têm sido esse povo. Não ouvem nem cedem. É inútil falar, aconselhar, pedir, ameaçar, em resumo, nada mais adianta. Nós
}

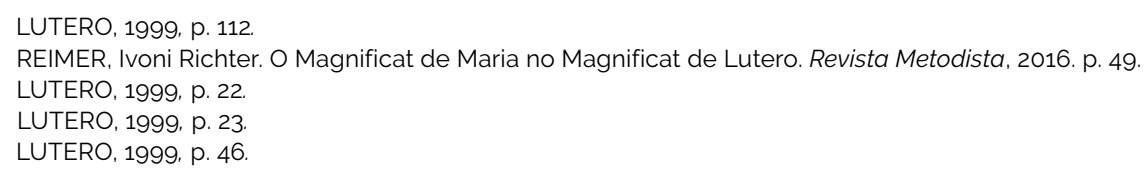


estamos com a razão e pronto. Diga o contrário quem quiser, ainda que seja o mundo inteiro. ${ }^{8}$

"Estes são os tesouros da inexplicável misericórdia divina, que não recebemos por merecimento, mas exclusivamente por graça".59 Essas são ideias teológicas já defendidas por Lutero em suas 95 teses, conforme exposição de algumas delas abaixo, de acordo com seu Debate sobre a Teologia Escolástica:

Tese 4: Por isso, é verdade que o ser humano, sendo árvore má, não pode-se não querer fazer o mal; Tese 9: Mesmo assim, por natureza e inevitavelmente ela é má e de natureza viciada; Tese 21: Nada há na natureza senão atos de concupiscência contra Deus; Tese 28: "Tornaivos para mim, e eu me tornarei para vós outros" (Zc 1,3); "Chegai-vos a Deus, e Ele se chegará a vós outros" (Tg 4,8); "Buscai e achareis" (Mt 7.7); "Quando me buscardes serei achado de vós" (Jr 29,31s); Afirmar, a respeito destas e de outras passagens semelhantes, que uma parte cabe à natureza e a outra à graça, não é outra coisa que sustentar o que disseram os pelagianos; Tese 54: Para o ato meritório basta a coexistência da graça; do contrário, a coexistência nada é; Tese 56: Deus não pode aceitar o ser humano sem a graça justificante de Deus; Tese 65: Fora da graça de Deus é a tal ponto impossivel não ser tomado de ira ou de cobiça, que nem mesmo na graça isso pode suceder de forma a cumprir perfeitamente a lei; Tese 68: Portanto, sem a graça de Deus é impossivel cumprir a lei, seja de que maneira for; Tese 71: Sem a graça de Deus, a lei e a vontade são dois adversários implacáveis; Tese 75: Mas a graça de Deus faz abundar a justiça através de Jesus Cristo, porque torna agradável a lei; Tese 76: Toda obra da lei sem a graça de Deus parece ser boa exteriormente. mas interiormente é pecado. ${ }^{60}$

\section{Lutero tem um posicionamento claro a respeito} das obras como também da justificação pela fé.

Esta é a opinião de São Paulo em muitas passagens, nas quais atribui tanto a fé, que chega a dizer: "Justus ex fide sua vivit", é da fé que a pessoa justa tem sua vida, e é por causa da fé que ela é considerada justa perante Deus. Se a justiça consiste na fé, fica claro que somente esta cumpre todos os mandamentos e torna justas todas as suas obras; por outro lado, sem a fé as obras não conseguem justificar a ninguém, perante Deus. ${ }^{61}$
No que se relaciona ao valor das obras como valor da indulgência para vivos e falecidos, Lutero menciona em seu Debate para o Esclarecimento do valor das Indulgências, em 1518: "Qualquer cristão verdadeiramente arrependido tem direito à remissão plena de pena e culpa, mesmo sem carta de indulgência62;" "Vã é a confiança na salvação por meio de cartas de indulgências, mesmo que o comissário ou até mesmo o próprio papa dê sua alma como garantia pelas mesmas".63

Pode-se acreditar que a reflexão do Magnificat apresenta também sinais da nova teologia criada por Lutero e seus amigos.

\section{Desdobramentos atuais do Magnificat}

Assim como Lutero, outros autores, teólogos e teologias se utilizaram do Magnificat para fazerem suas reflexões e analogias. Pretende-se agora expor alguns dos desdobramentos teológicos dessas reflexões:

a) Teologia da libertação: Tomamos a liberdade de incluir como atualização do Magnificat para essa teologia, o poema "Mariama", que parafraseia o Magnificat, de Dom Hélder Câmara, extraido do texto da Missa dos Quilombos de $2003^{64}$ :

Mariama, Nossa Senhora, mãe de Cristo e mãe dos homens!

Mariama, mãe dos homens de todas as raças, de todas as cores, de todos os cantos da Terra.

Pede a teu filho que esta festa não termine aqui, a marcha final vai ser linda de viver.

Mas é importante, Mariama, que a Igreja de teu fitho não fique em palavras, não fique em aplausos.

O importante é que a CNBB, a Conferência dos Bispos, embarque de cheio na causa dos negros.

Como entrou de cheio na pastoral da terra e na pastoral dos indios.

Não basta pedir perdão pelos erros de ontem.

\footnotetext{
LUTERO, 1999, p. 73.

LUTERO, 1999, p. 103

LUTERO, 2004, v. 1, p. 15-19

LUTERO, 2004, V. 1, p. 108.

LUTERO, 2004. v. 1. p. 25

LUTERO, 2004, v. 1, p. 26.
}

CONDINI, Martinho. Dom Hélder Câmara: modelo de esperança na caminhada para a paz e a justiça social. Dissertação de mestrado. São Paulo: PUCSP, 2004. p. 76. 
É preciso acertar o passo de hoje sem ligar ao que disserem.

Claro que dirão, Mariama, que é política, que é subversão, que é comunismo.

É Evangelho de Cristo, Mariama!

Mariama, mãe querida, problema de negro acaba se ligando com todos os grandes problemas humanos.

Com todos os absurdos contra a humanidade, com todas as injustiças e opressões.

Mariama, que se acabe, mas se acabe mesmo a maldita fabricação de armas.

O mundo precisa fabricar é paz.

Basta de injustiças!

Basta de uns sem saber o que fazer com tanta terra e milhões sem um palmo de terra onde morar.

Basta de uns tendo que vomitar para comer mais e 50 milhões morrendo de fome num só ano.

Basta de uns com empresas se derramando pelo mundo todo e milhões sem um canto onde ganhar o pão de cada dia.

Mariama, Nossa Senhora, mãe querida, nem precisa ir tão longe, como no teu hino.

Nem precisa que os ricos saiam de mãos vazias e os pobres de mãos cheias.

Nem pobre, nem rico!

Nada de escravo de hoje ser senhor de escravos amanhã.

Basta de escravos!

Um mundo sem senhores e sem escravos.

Um mundo de irmãos.

De irmãos não só de nome e de mentira.

De irmãos de verdade, Mariama!

Maria proclama que Deus faz uma grande transformação em âmbito social, ou seja, a Boa Nova de Jesus tem mudanças estruturais, ela atinge a realidade do povo e, por isso, exige mudança no exercício do poder e na distribuição dos bens. $\mathrm{O}$ Magnificat proclama de forma transformadora a ação de Deus que renova todas as coisas, inclusive nas relações sociais. Aborda a chateação contra a injustiça que age de forma suprema no mundo. Declara e denuncia o mau uso do poder público e a concentração dos bens materiais nas mãos de poucos. Entretanto, ela nos mostra que nossa esperança está em Deus e na sua misericórdia, que por fidelidade sempre protege e socorre seu povo.
Em Is 10,1 verifica-se: "Ai dos que promulgam leis injustas e redigem medidas maliciosas, para tapear o fraco na justiça, roubar o direito do meu povo explorado, para fazer da viúva suas vítimas e para roubar os órfãos". Enfim, Deus não aprova a exploração, ao contrário, Ele é um Deus de justiça que tem preferência pelos pobres.

b) Teologia e ecologia: O sentido da reflexão do Magnificat com a ecologia refere-se a que esse é um canto de libertação e que não dá para pensar em libertação da pessoa, sem pensar em todas as suas nuances, ou seja, sem pensá-la a nivel cósmico. Justifica-se esse pensamento, porque a lógica da opressão em relação ao pobre é a lógica utilizada para exploração e degradação da natureza; tudo tem um viés de lucro. Enfim, a vida social muitas vezes gira em torno de objetivos negligentes que ameaçam tanto a vida da pessoa como a do Planeta. É necessário um mundo onde a sustentabilidade seja o cerne do pensamento de desenvolvimento, não esquecendo jamais da verdadeira distribuição de renda, ou seja, sem exploração humana e sem exploração ambiental.

c) Teologia e economia: Maria anuncia que Deus, o Todo Poderoso, enche de bens os famintos. Nessa linha, lembremos que Deus sempre deseja saciar suas criaturas conforme podemos avaliar em vários textos da Escritura, tanto no Antigo como no Novo Testamento, a saber: Deus que alimenta seu povo com o Maná no deserto ou ainda Jesus que multiplica os pães para as pessoas que escutam suas palavras.

O Magnificat, hoje, poderia ser utilizado para denunciar o neoliberalismo que oprime a sociedade. "Não preocupar-se com os sofrimentos dos outros, no caso o desemprego, a fome, a miséria, é o mesmo que dizer que Deus não se importa com seus filhos". ${ }^{5}$ Em Jo 10,10: "Eu vim para que todos tenham vida, e a tenham em abundância", verifica-se o sentido de uma fé, que como Maria em seu cântico, não é somente de foro íntimo, mas tem a largueza da cruz de Jesus, é para todos, ou seja, a vida digna é para todo o povo. 


\section{Considerações finais}

O Magnificat de Maria interpretado por Martinho Lutero apresenta considerações importantíssimas para a vida cristã atual. O Magnificat é um belo roteiro de exaltação a Deus que demonstra e adverte que tudo inicia pelo enaltecimento a Deus, a vida, a alma, o espírito focado naquele que é, que tudo fez e que tudo pode fazer e faz.

Comumente durante sua interpretação, Lutero aborda a preferência de Deus de olhar para baixo, para os considerados pela sociedade como insignificantes. Esse é um grande desafio lançado por Jesus. Jesus visitou, cuidou, curou e amou os pobres, os doentes, os cobradores de impostos e tantos outros. Sua afirmação: "quem precisa de médico são os doentes" (Mc 2,17), se confirma em seus atos, no seu modo de agir.

Deus olha para baixo, olha para a humanidade. Os cristãos são convidados a olharem para baixo. A lógica de Deus não é a humana, mas é a verdade. Maria, por meio do Magnificat, exorta ao aprendizado por meio da graça: essa preferência do Senhor parte do reconhecimento do humilde como humilhado e da sua total confiança n'Ele. A partir dai Deus pode agir e transformar todas as coisas, através da sua misericórdia. Lutero escreve o Magnificat respondendo uma pergunta do príncipe Frederico. Nesse viés, o Cântico de Maria torna-se um roteiro de ética política. A resposta de Lutero é tão atual o quanto foi em sua época. "Não lembro nada que sirva melhor para esse caso do que o cântico sagrado da bendita mãe de Deus".6 6 Ele é atual na medida em que denuncia o quanto de corrupção e articulação em beneficio próprio os governantes e ricos de hoje compactuam, refletindo exatamente o oposto daquilo que a Virgem Mãe de Deus proclama e faz.

O chamamento de Maria é de sair de si para os outros e sem jamais utilizar dos bens que o Senhor proporciona para cometer injustiça. Ao contrário, a prática dos governantes e ricos deve focar no bem-comum. A partir dessas reflexões, não se deve ignorar a premissa de Rui Barbosa:
"De tanto ver prosperar a desonra, de tanto ver crescer a injustiça, de tanto ver agigantarem-se os poderes nas mãos dos maus, o homem chega a desanimar da virtude, a rir-se da honra, a ter vergonha de ser honesto."67 Quando a ação de Deus age e impulsiona as atitudes pessoais, uma sociedade melhor se descortina.

Que católicos e luteranos não concordam em algumas teses e dogmas teológicos sabe-se de longa data, mas o essencial é registrar que em outros importantes elementos da fé concordam profundamente, a saber: a maternidade virginal de Maria como mãe de Jesus, Filho de Deus e Maria como um modelo de fé e de apostolado.

O exercício de elaboração desse artigo foi de grande relevância e aprendizado entre as partes, já que uma das autoras é luterana e a outra católica. Destaca-se que ambas acreditam que o diálogo ecumênico autêntico se faz por meio de atividades como essa e que a troca de experiência, de conhecimento e a convivência é valiosa para a construção de um mundo de paz. Nesse sentido ecumênico, as palavras de Lutero nos impulsionam para um convite:

\begin{abstract}
Queira essa doce mãe de Deus conquistar para mim o espírito capaz de interpretar de forma proveitosa e profunda esse cântico. Assim Vossa Alteza e todos nós podemos compreendê-lo bem e ter uma vida louvável para que, na vida eterna, possamos louvar $e$ cantar esse Magnificat eterno. Que Deus nos ajude. Amém. ${ }^{68}$
\end{abstract}

São palavras que nos incentivam a novos encontros e projetos, em que desafios e planejamentos proporcionam ensaios misericordiosos na compreensão dos outros e das outras em nosso caminho.

\section{Referências}

ATANÁSIO. Serm. 13 de tempore; PL 39, 1907.

BÍBLIA. Português. A Biblia de Jerusalém. Nova edição revista e ampliada. São Paulo: Paulus, 2004.

\footnotetext{
LUTERO, 1999, p. 12

Diponivel em: https://dcomercio.com.br/categoria/opiniao/a-miseria-moral. Acesso em: 11 set. 2020.

68 LUTERO, 1999, p. 9.
} 
BÍBLIA SAGRADA COM REFLEXÕES DE LUTERO. Nova tradução na linguagem de hoje. São Paulo: Sociedade Bíblica do Brasil, 2016

COMISSÃO TEOLÓGICA INTERNACIONAL DA ASSOCIAÇÃO ECUMÊNICA DE TEÓLOGOS/AS DO TERCEIRO MUNDO. Descer da cruz os pobres: cristologia da libertação. São Paulo: Paulinas, 2007.

CONCÍLIO ECUMÊNICO VATICANO II. Constituição Dogmática Lumen Gentium: sobre a Igreja. In: COSTA, Lourenço (org. geral). Documentos do Concilio ECumênico Vaticano II (1962-1965). 4. ed. Trad. Tipografia Poliglota Vaticana. São Paulo: Paulus, 2007. p. 101-197.

CONDINI, Martinho. Dom Hélder Câmara: modelo de esperança na caminhada para a paz e a justiça social. Dissertação (Mestrado) -- PUCSP, São Paulo, 2004

CONSELHO EPISCOPAL LATINO-AMERICANO. DoCUmento de Aparecida: texto conclusivo da $V$ Conferência Geral do Episcopado Latino-Americano e do Caribe. 3. ed. Trad. Luiz Alexandre Solano Rossi. Brasília: Edições CNBB; São Paulo: Paulus; Paulinas, 2007.

FRANCISO, Papa. Misericordiae Vultus: bula de proclamação do Jubileu Extraordinário da Misericórdia Brasilia: CNBB, 2015.

GONZÁLEZ, Carlos Ignácio. Maria evangelizadora e evangelizada. São Paulo: Loyola, 1990

LUTERO, Martim. Obras selecionadas: os primórdios (escritos de 1571 a 1519). São Leopoldo: Sinodal; Porto Alegre: Concórdia, 2004. v. 1.

LUTERO, Martim. Obras selecionadas: o programa da Reforma (escritos de 1520). São Leopoldo: Sinodal; Porto Alegre: Concórdia, 2004. v. 2.

LUTERO, Martim. O louvor de Maria: o Magnificat. São Leopoldo: Sinodal, 1999

MURAD, Afonso. Maria, toda de Deus e tão humana. São Paulo: Paulinas, 2004

ORDINE, Roberto Mateus. A miséria moral. Diário do comércio, São Paulo, 2015. Disponível em: https:// dcomercio.com.br/categoria/opiniao/a-miseria-moral.

PERETTI, Clélia (org.). Congresso de teologia da PUCPR. Curitiba: Anais Eletrônicos, 2011.

REIMER, Ivoni Richter. O Magnificat de Maria no Magnificat de Lutero. Revista Metodista, [S. l.], v. 30, n. 2 , p. 41-69, 2016. https://doi.org/10.15603/2176-1078/ er.v30n2p41-69.

SOBRINO, Jon. O Deus que liberta seu povo: a fé em Jesus Cristo. Ensaio a partir das vítimas. Rio de Janeiro: Vozes, 2000

SUNG, Jung Mo. Deus e idolo na economia. São Paulo: Paulus, 1992.

SUNG, Jung Mo. Debate Teologia e Economia: A Idolatria do Mercado e os Desafios Pastorais. Contexto Pastoral, São Paulo, n. 18, jan./fev. 1994. Suplemento.

\section{Janaina Santos Reus Freitas}

Mestre em teologia pela Universidade Católica do Rio Grande do Sul (PUCRS), em Porto Alegre, RS, Brasil. Assessora pedagógica da $11 .{ }^{a}$ Coordenadoria Regional de Educação, docente em Ensino Religioso, assessora em mediação de conflitos.

\section{Edla Eggert}

Doutora em teologia pela Escola Superior de Teologia (Faculdades EST); mestre em educação pela Universidade Federal do Rio Grande do Sul (UFRGS), em Porto Alegre, RS, Brasil; professora na Escola de Humanidades da Universidade Católica do Rio Grande do Sul (PUCRS), em Porto Alegre, RS, Brasil; coordenadora da Pós-Graduação em Educação da PUCRS.

\section{Endereço para correspondência}

Janaina Santos Reus Freitas/ Edla Eggert

Pontificia Universidade Católica do Rio Grande do Sul

Av. Ipiranga, 6681, Prédio 15, sala 217

Partenon, 90619900

Porto Alegre, RS, Brasil 